Kalsbeek, F. \& Pidgeon, R. T. 1980: The geological significance of Rb-Sr whole-rock isochrons of polymetamorphic Archaean gneisses, Fiskenæsset area, southern West Greenland. Earth planet. Sci. Lett. 50, 225-237.

Larsen, O. 1969: K/Ar age determinations. Rapp. Grønlands geol. Unders. 19, 62-67.

Moorbath, S. \& Pankhurst, R. J. 1976: Further rubidium-strontium age and isotope evidence for the nature of the late Archaean plutonic event in West Greenland. Nature 262, 62-67.

Nielsen, T. F. D. \& Escher, J. C. 1985: Preparation for the South-East Greenland mapping project 1986-1987. Rapp. Grønlands geol. Unders. 125, 84-87.

Pedersen, S., Larsen, O., Bridgwater, D. \& Watterson, J. 1974: Rb/Sr whole-rock isochron age determinations on metamorphosed acid volcanic rocks and granitic gneisses from the Ketilidian mobile belt, South-East Greenland. Rapp. Grønlands geol. Unders. 66, 12-20.

Taylor, P. N., Moorbath, S., Goodwin, R. \& Petrykowski, A. C. 1980: Crustal contamination as an indicator of the extent of early Archaean crust: $\mathrm{Pb}$ isotopic evidence from the late Archaean gneisses of West Greenland. Geochim. cosmochim. Acta 44, 1437-1453.

O. L.,

Institut for Petrologi,

Københavns Universitet,

Øster Voldgade 10 ,

DK-1350 Copenhagen $\mathrm{K}$,

Denmark.
P. N. T.,

Department of Earth Sciences, University of Oxford, Oxford OX1 3PR,

U.K.

\title{
Oil geological studies in central East Greenland
}

\section{S. Piasecki and C. Marcussen}

Field work undertaken in central East Greenland during August 1985 was a follow-up of the oil geological studies by GGU expeditions to Jameson Land in 1982 and 1983 (Surlyk, 1983; Surlyk et al., 1984a). Three major subjects were covered by the field work.

The Permian-Triassic boundary was studied along the western margin of the Jameson Land basin (Surlyk et al., 1984b). A series of closely sampled sections along the exposures of the eastern part of the Schuchert Dal was completed. The sampled material will be analysed with respect to source rock quality, maturity and stratigraphy.

Secondly, the analysis of the regional maturity in southern Jameson Land based on the material from the 1982-83 expeditions indicates a specific surface maturation pattern (Piasecki, 1985; Thomsen, 1985) which had to be confirmed or rejected by analyses of further material from localities throughout the area. New material was collected along Hurry Inlet and in the southern and western parts of Jameson Land. Maturity studies will be supplemented by stratigraphical and geochemical analyses at these localities.

The third target of the field work was to start oil geological studies of the area north of Kong Oscar Fjord, and to locate drill sites for shallow-core drilling in immature potential source rocks. The island of Traill $\emptyset$ was visited for two days of helicopter reconnaissance. Wollaston Forland was visited for two days at the end of the season in co-operation with geologists of a British Petroleum (BP) party working in this area. Material was collected for preliminary source rock studies and biostratigraphy. 
In addition to the field work, the base camp of the Atlantic Richfield Company (ARCO) at Constable Pynt in Hurry Inlet was visited. During our stay, a crew from Geophysical Service Inc. (GSI) located the cross and end-points of the seismic lines of the planned geophysical exploration using a satellite navigation system. We followed their work during one night in western Jameson Land.

\section{The Permian-Triassic boundary stratigraphy}

The Permian-Triassic boundary is associated with a global hiatus which in combination with strong provincialism of flora and fauna in this time interval has complicated the development of a biostratigraphy with more than regional applicability.

In East Greenland, the Upper Permian sediments are characterised by the occurrence of the ammonite Cyclolobus kullingi. This occurrence indicates a mid-Permian or possibly Late Permian age for these sediments (Waterhouse, 1972). Conodont faunas from the sequences at Kap Stosch (Sweet, 1976) and from Jameson Land (S. Stouge in Perch-Nielsen et al., 1972) indicate a Late Permian age.

In contrast, the Lower Triassic sediments are subdivided in detail by ammonite zonation (Spath, 1930, 1935; Grasmück \& Trümpy, 1969; Teichert \& Kummel, 1976). Unfortunately, the more precisely described ammonite stratigraphy is restricted to two small regions: Wegener Halvø (Grasmück \& Trümpy, 1969) and Kap Stosch at Hold With Hope (Spath, 1930, 1935; Teichert \& Kummel, 1976). Some limited information on the ammonite stratigraphy of the Lower Triassic sediments of the Schuchert Dal area is cited in the papers mentioned above, mainly as personal communications from $\mathbf{M}$. Aellen who worked in this area during two periods. It is, however, very difficult to locate precisely the ammonite assemblages in the sections which are very vaguely described. This stratigraphic information is therefore of restricted value. More precise information from a few localities based on Aellen's latest field work is found in Perch-Nielsen et al. (1972).

Balme (1979) established a palynostratigraphy across the Permian-Triassic boundary at Kap Stosch, and Piasecki (1983) extended this stratigraphy in a preliminary form to the Jameson Land region. The establishment of an Upper Permian - Lower Triassic palynostratigraphy in Jameson Land must be based on the sequence along eastern Schuchert Dal where the maturity of the organic matter is low, the lithological units occur as fine-grained facies and the most complete units are exposed.

A complete Upper Permian sequence is exposed in an unnamed valley, south of Rødstakken in Gurreholm Bjerge (locality 6, fig. 1). The uppermost part, the silty shale of the Oksedal Member, Schuchert Dal Formation (Surlyk et al., unpublished MS) is interrupted by only three sandstone bodies, the uppermost one at the Permian-Triassic boundary. The lowermost Triassic sequence is displaced by a major fault.

At Triaselv most of the Upper Permian sequence is well exposed along the outer part of the river, but the main lower part of the Oksedal Member is not exposed due to displacement by a major fault at the mouth of the canyon. The boundary strata and the lowermost Triassic sequence are, on the other hand, very well exposed and complete. The boundary is marked by a thin sandstone bed, succeeded by bioturbated and then laminated silty shale. A well preserved ammonite assemblage was collected in the basal $9 \mathrm{~m}$ of this shale (locality 5). The ammonites probably indicate the Martini Zone, and the boundary therefore includes a small hiatus equivalent to at least the Triviale Zone. 


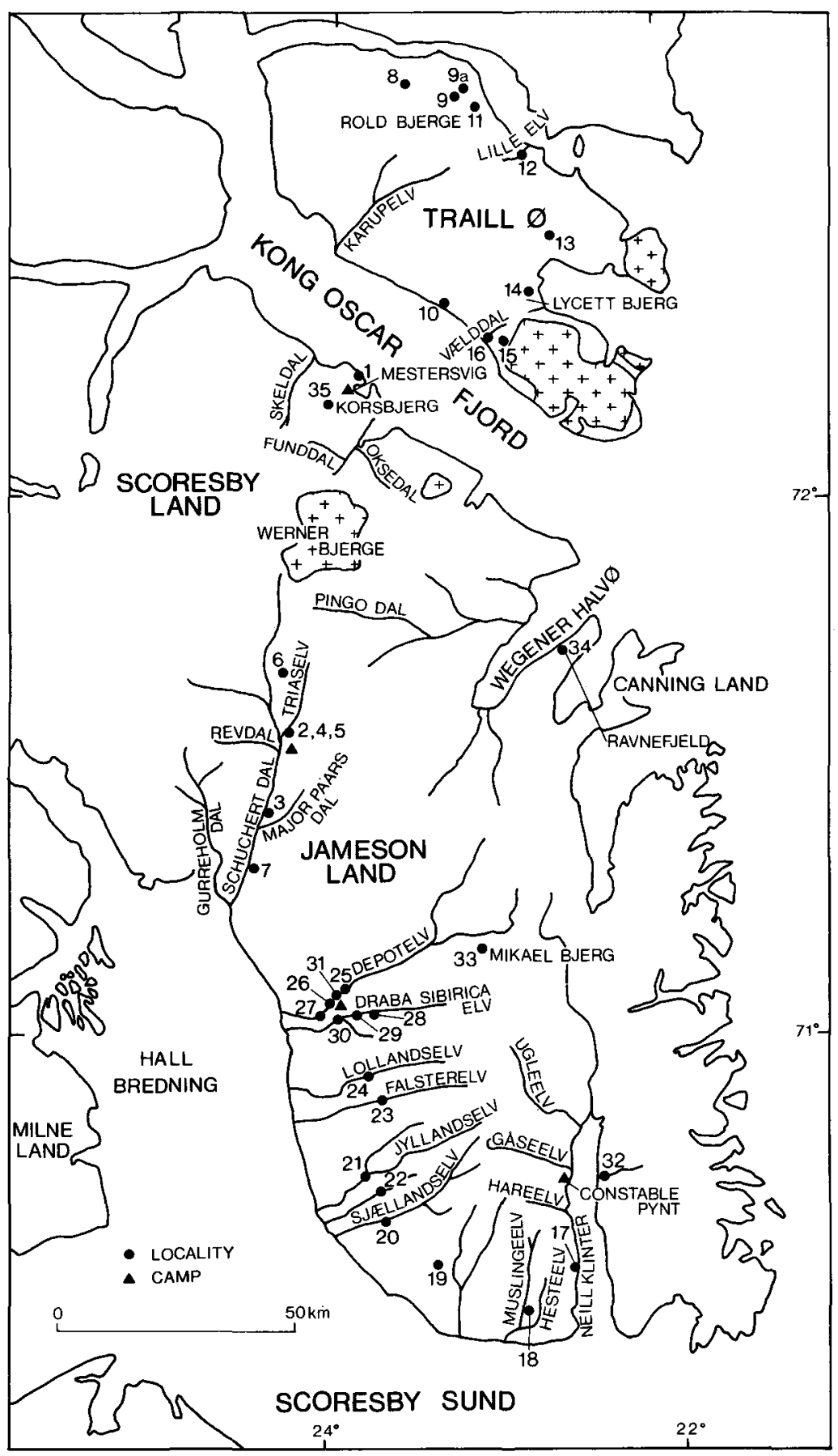

Fig. 1. Locality map of Jameson Land and Traill $\emptyset$. The Tertiary intrusions of northern Jameson Land and Traill $\emptyset$ are indicated by crosses. 


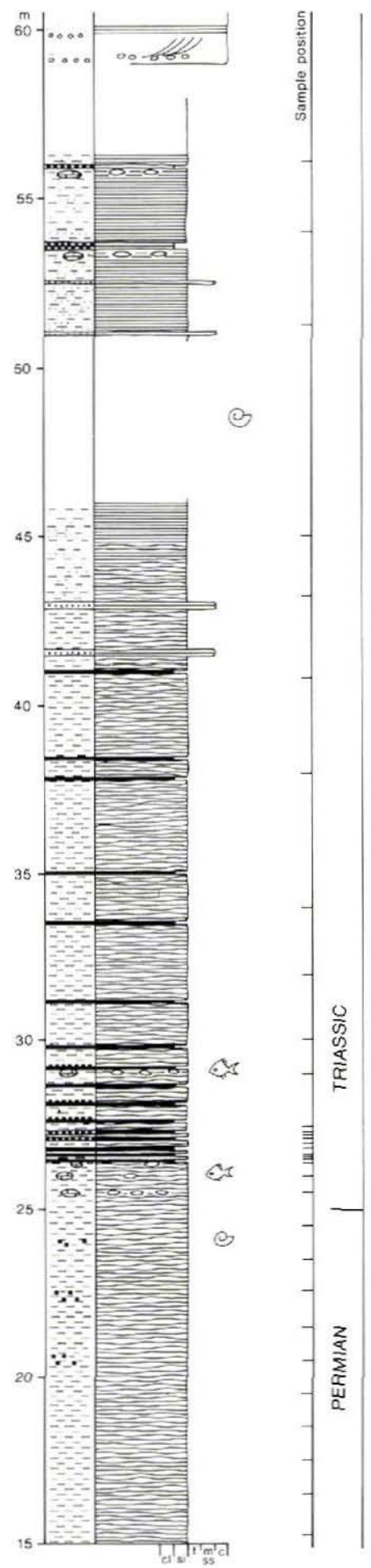

Fig. 2. Section 3 from western Jameson Land showing the transition from the Upper Permian Oksedal Member, Schuchert Dal Formation, to the Lower Triassic Wordie Creek Formation.

LEGEND

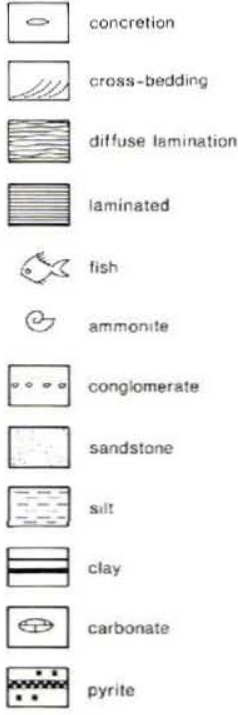


The lowermost Triassic shale is followed by a sand and conglomerate unit of turbidite origin (Surlyk et al., 1984b). A second interval of bioturbated, silty shale becoming laminated in the upper part, is succeeded by a series of sandstone beds, occasionally separated by thin brown and green shale beds. The shaly intervals were closely sampled for palynology (locality 2).

At the edge of Schuchert Dal, just north of Major Paars Dal, a small outcrop that includes a section through the Permian-Triassic boundary was visited (locality 3 ). The locality was originally reported by S. Stouge (unpublished field diary 1971 at GGU). The section was remeasured and closely sampled (fig. 2). The Permian-Triassic boundary is not reflected here by sharp lithological breaks (i.e. sandstone beds) and the Martini Zone is represented by ammonites in loose concretions from a level approximately $20 \mathrm{~m}$ above the boundary (Perch-Nielsen et al., 1972). This indicates continuous sedimentation across the boundary and the presence of Triassic sediments, possibly older than the Martini Zone. The section is therefore the most complete boundary section exposed in Jameson Land.

Concretions and thin clay beds are concentrated around the boundary, but are also present throughout the remaining part of the section. The thin clay beds at the boundary were carefully sampled for geochemical trace element analysis.

Perch-Nielsen et al. (1972) report that the boundary interval can be restricted to approximately $4 \mathrm{~m}$ between the latest occurrence of the Permian ammonite Cyclolobus kullingi and concretions with Triassic fishes, and they tentatively place the boundary at the lowest clay bed. A concretion containing fish scales and teeth was found $0.5 \mathrm{~m}$ below the lowest clay bed. The fish remains have been identified as the mainly Triassic genus Bobasatrania (B. cf. groenlandica; S. E. Bendix-Almgreen, personal communication, 1985).

The new samples from this section have been palynologically prepared. The organic matter of the sediments shows a clear variation through the sequence. In the lower part, the Oksedal Member, the organic matter is composed of terrestrial material. Coalified, angular tracheids dominate over pollen and spores. This composition changes to a pollen and spore dominance approximately $1 \mathrm{~m}$ below the first clay bed, and this is maintained up to the first pyritic clay bed in the Wordie Creek Formation (fig. 2). From this bed and up throughout the sequence, the organic matter is composed of amorphous kerogen and sporomorphs. The content of organic matter is low throughout the sequence $(<1 \% \mathrm{TOC})$.

The sequence can therefore be divided into three palyno-facies of which the two lowest are closely related. The boundaries reflect changes in the depositional environment, and both of these occur within the palaeontologically demarcated Permian-Triassic boundary interval.

The lowest and least significant change of palyno-facies coincides with a massive influx of trilete, cavate spores, which may be taken as an indicator of the Permian-Triassic boundary. Higher in the sequence, these spores are a less prominent but persistent fraction of the sporomorph assemblage as in all other analysed Lower Triassic sequences in Jameson Land. Bisaccate, striate pollen dominate the sporomorph assemblage throughout the section, with the exception mentioned above.

\section{Regional maturity in southern Jameson Land}

In the summer of 1983 three shallow cores were drilled through the upper part of the Hareelv Formation at a locality in Sjællandselv close to Salix Dal (Surlyk et al., 1984a). Several 
additional sections were sampled in the area around the drilling site, and the analyses of the samples showed that the organic matter in the sediments at Salix Dal was postmature with regard to oil generation (Piasecki, 1985; Thomsen, 1985). In contrast, the organic matter in sediments from the shallow cores and the exposed sections closer to the drill site at Sjallandselv was only marginally mature. The high maturity could either be very local, induced by closely spaced Tertiary basalt sills and dykes which are very common in southern Jameson Land, or it could be the margin of a larger postmature area extending south-west towards Scoresby Sund. The intention in $\mathbf{1 9 8 5}$ was to analyse this problem by systematic sampling of sections along the southern and western coast of Jameson Land.

During the present field work eight sections (localities 17-24) along the coast were sampled during helicopter reconnaissance and further seven sections (localities 25-31) were sampled in a smaller area at Depot Elv and Draba Sibirica Elv from a field camp (fig. 1). All the sections were selected in order to avoid any influence from intrusive bodies and should therefore reflect the maturity of the region. The samples are from Lower Cretaceous to Middle Jurassic sediments, and the lithology varies from sandy silt to clay shales.

The maturity of the organic matter will be determined by measurement of the vitrinite reflectance and by estimating the Thermal Alteration Index (TAI) of sporomorphs.

The Jameson Land basin is bounded to the east by the crystalline basement rocks of the Liverpool Land high. Devonian, Carboniferous, Permian and Triassic sediments onlap this high in the north. In the southern part of the basin around Hurry Inlet, the fjord separates the Mesozoic sediments of the basin from the crystalline rocks of Liverpool Land. However, Bütler (1957) and Coe (1975) describe a sequence of granitic, residual conglomerate followed by sandstone, green and black shale and carbonate from the west coast of Liverpool Land adjacent to Hurry Inlet. These steeply dipping sediments (up to $64^{\circ}$ westwards) are overlain by Triassic sediments in a small area at the head of Hurry Inlet and are the oldest sediments exposed in this part of the basin. The sequence has not been dated beyond the level 'pre-Triassic', as no macrofossils have been found.

A locality at Damelv (locality 32) was briefly visited in 1985 and a sequence of finegrained sediments (black carbonate and clay shale) was sampled for palynological dating and maturation studies. The general appearance of the sediments indicates a high level of thermal diagenesis, but it is hoped that some sporomorphs will yield the basis for age determination.

\section{Oil geological studies north of Kong Oscar Fjord}

GGU is planning petroleum geological field work north of Jameson Land. In 1985 a number of localities on Traill $\emptyset$ were visited during two days of helicopter reconnaissance in order to prepare for field work in 1986 and 1987. Sediment samples were collected from surface exposures to gain a first impression of regional maturity, occurrence and distribution of potential source rocks, and to select the first localities for shallow core-drilling.

The geological map of Traill $\emptyset$ by Koch \& Haller (1971) indicates that the island consists of four major regions or fault blocks with progressively eastwards down-faulting along normal faults. A Devonian dominated region in the west is bounded to the east by a downfaulted Carboniferous to Lower Triassic block and a Cretaceous block. Furthest to the east is found a block dominated by Jurassic sediments and Tertiary magmatic intrusions.

The Devonian block was not visited. The eastern region with intrusives was considered 
to have no prospects due to the presumed heating of the surrounding sediments; similar conditions were found in northern Jameson Land near the line of intrusions which extends from Werner Bjerge towards eastern Traill $\varnothing$ (fig. 1) (Piasecki, 1985; Thomsen, 1985).

The purpose of the present field work was to establish a regional grid of maturity data, so that the maturity of the surface sediments within each block could be estimated.

The Carboniferous - Lower Triassic block had previously been sampled at two localities, Rubjerg Knude and Kongeborgen. A locality of Carboniferous sediments at the north coast of Traill $\varnothing$ (locality 8 ) was visited in 1985 . However, in contrast to the Kongeborgen locality, these sediments were found to be very poor in fine-grained, organic-rich sediments, with the exception of one bed. The subsequent visit to the northern flank of Rold Bjerge (locality 9a) was disappointing because the Upper Permian sediments here were very badly exposed. The Wordie Creek Formation was, on the other hand, well exposed and provided adequate material for analyses.

At the southern coast of Traill $\emptyset$ (locality 10) the exposures of Upper Permian sediments were sampled at the eastern boundary of the block. The Lower Triassic part of the section is, however, dissected by thick basalt sills strongly affecting the sediments.

The exposures of Cretaceous sediments in the Cretaceous block suffer from intrusion of basalt sills and dykes. Most exposures are present only because of the resistance to erosion of the intrusive bodies. Otherwise, the black shales are easily eroded and form rounded hills due to solifluction. However, a few small stream sections appear to be devoid of thermal influence. Six localities (localities 11-16) were sampled for maturation studies and three of these were selected as possible drill sites for the planned work in 1986 (localities 13,14 \& 16). Maturity and geochemical analyses will provide the data for a final decision on selection of the drill sites.

\section{References}

Balme, B. E. 1979: Palynology of Permian-Triassic boundary beds at Kap Stosch, East Greenland. Meddr Grønland 200(6), 37 pp.

Bütler, H. 1957: Beobachtungen an der Hauptbruchzone der Küste von Zentralostgrönland. Meddr Grønland 160(1), 79pp.

Coe, K. 1975: The Hurry Inlet granite and related rocks of Liverpool Land, East Greenland. Bull. Grønlands geol. Unders. 115, 34 pp.

Grasmück, K. \& Trümpy, R. 1969: Triassic stratigraphy and general geology of the country around Fleming Fjord (East Greenland). Meddr Grønland 168(2), 5-71.

Koch, L. \& Haller, J. 1971: Geological map of East Greenland $72^{\circ}-76^{\circ} \mathrm{N}$ lat. Meddr Grønland 183, 26 pp.

Perch-Nielsen, K., Bromley, R. G., Birkenmajer, K. \& Aellen, M. 1972: Field observation in Palaeozoic and Mesozoic sediments of Scoresby Land and northern Jameson Land. Rapp. Grønlands geol. Unders. 48, 39-59.

Piasecki, S. 1983: Preliminary palynostratigraphy of the Permian - Lower Triassic sediments in Jameson Land and Scoresby Land, East Greenland. Bull. geol. Soc. Denmark 32, 139-144.

Piasecki, S. 1985: Palynological evaluation of the regional thermal maturation of Carboniferous to Tertiary sediments in central East Greenland. Unpubl. Intern. Rep. Grønlands geol. Unders. 31-1-1985, $51 \mathrm{pp}$.

Spath, L. F. 1930: The Eotriassic invertebrate fauna of East Greenland. Meddr Grønland 83(1), 90 pp.

Spath, L. F. 1935: Additions to the Eo-Triassic invertebrate fauna of East Greenland. Meddr Grønland 98(2), $115 \mathrm{pp}$. 
Surlyk, F. 1983: Source rock sampling, stratigraphical and sedimentological studies in the Upper Palaeozoic of the Jameson Land basin, East Greenland. Rapp. Grønlands geol. Unders. 115, 88-93.

Surlyk, F., Hurst, J. M., Marcussen, C., Piasecki, S., Rolle, F., Scholle, P. A., Stemmerik, L. \& Thomsen, E. 1984a: Oil geological studies in the Jameson Land basin, East Greenland. Rapp. Grønlands geol. Unders. 120, 85-90.

Surlyk, F., Piasecki, S., Rolle, F., Stemmerik, L., Thomsen, E. \& Wrang, P. 1984b: The Permian Basin of East Greenland. In: Spencer, A. M. et al. (edit.) Petroleum geology of the North European margin. Graham \& Trotman Ltd. for the Norwegian Petroleum Society, 303-315.

Surlyk, F., Frazier, T., Harpøth, O., Hurst, J. M., Piasecki, S., Rolle, F., Scholle, P. A. \& Stemmerik, L.: Lithostratigraphy of the Upper Permian Foldvik Creek Group, East Greenland. Unpublished manuscript 1986.

Sweet, W. C. 1976: Conodonts from the Permian-Triassic boundary beds at Kap Stosch, East Greenland. Meddr Grønland 197(5) Appendix, 51-54.

Teichert, C. \& Kummel, B. 1976: Permian-Triassic boundary in the Kap Stosch area, East Greenland. Meddr Grønland 197(5), $49 \mathrm{pp}$.

Thomsen, E. 1985: A coalification study of Upper Palaeozoic - Mesozoic deposits from central East Greenland. Unpublished Int. Rep. Grønlands geol. Unders. 1-9-1985, Parts I \& II, 54 pp.

Waterhouse, J. B. 1972: The evolution, correlation, and paleogeographic significance of the Permian ammonoid family Cyclolobidae. Lethaia 5, 251-270.

\section{Glaciological investigations at the margin of the Inland Ice north-east of Jakobshavn, West Greenland}

\section{Henrik Højmark Thomsen and Niels Reeh}

Glaciological field investigations have been carried out on the Inland Ice north-east of Jakobshavn. The work is a part of the hydropower investigations at Pâkitsoq in a drainage basin proposed for a local hydropower project.

\section{Drainage basin and glaciological setting}

The drainage basin at Pâkitsoq lies between $69^{\circ} 25^{\prime} \mathrm{N}$ to $69^{\circ} 32^{\prime} \mathrm{N}$ and $50^{\circ} 05^{\prime} \mathrm{W}$ to $50^{\circ} 20^{\prime} \mathrm{W}$ (fig 1). Excluding its Inland Ice sector the basin covers an area of $33.6 \mathrm{~km}^{2}$ and is situated at about $200-600 \mathrm{~m}$ a.s.l. The main part of the runoff from the basin is meltwater draining through three lakes, 326, 233 and 187, from the adjoining Inland Ice sector. Lake 187 is proposed as the main reservoir.

The basin contains four outlet glaciers from the Inland Ice (inventory nos 1GE07001-2, 1GE04001-2) and the central one, 1GE07001, terminates in lake 187. The glaciers have retreated since 1880 (Weidick, 1968). The thinning of glacier 1GE07001 between 1880 and 1959 is estimated by photogrammetric methods to be about $40 \mathrm{~m}$ near the margin, decreasing to about $20 \mathrm{~m}$ at $350 \mathrm{~m}$ a.s.l (Thomsen, 1983a). The meltwater from lake 233 to lake 187 